\title{
Socialization Of Community Participation In Bandar Khalifah Village Development Planning Precut Sei Tuan District
}

\author{
Lukman Nasution ${ }^{1}$, Abd. Rasyid Syamsuri ${ }^{2}$, Reza Nurul Ichsan ${ }^{3}$ \\ ${ }^{1,2}$ University of Muslim Nusantara Al Washliyah Medan, Sumatera Utara \\ ${ }^{3}$ University of Pembinaan Masyarakat Indonesia, Medan, Sumatera Utara \\ * Corresponding Author \\ Email: lukmanumnaw@gmail.com
}

\begin{abstract}
.
The results of observations of the main problems regarding to the activities or socialize participation community programs in the development planning of the Bandar Khalifa village, Percut Sei Tuan district include: a) The people of Bandar Khalifah Village, Percut Sei Tuan District, do not have knowledge about village development planning. b) The people in Bandar Khalifah Village, Percut Sei Tuan District, do not understand the participation activities that can be conducted by them in the village development planning. This activity was conducted in Bandar Khalifah Village, Percut Sei Tuan District in June, 2021. This socialization activity involved village heads and the community in Bandar Khalifah Village, Percut Sei Tuan District and hopefully the participants will be able to implement village development planning activities to encourage sustainable achievements. The conclusions obtained from the results of community service activities in Bandar Khalifah Village, Percut Sei Tuan District are: a) There is a material conformity with the needs of the community to understand the socialization of community participation in village development planning. b) There is a positive response from the community which is shown through discussions in terms of achieving village development planning in Bandar Khalifah Village, Percut Sei Tuan District.
\end{abstract}

Keywords: Socialization, community participation, village development

\section{INTRODUCTION}

Development essentially aims to create a fair and prosperous society that is equitable and equal. Development begins with development planning to plan development programs that will be implemented in the future. The success of a development program is not only based on the ability of the government, but is also related to community participation in conducting the development programs. [1] The implementation of community participation in development is crucial in every stage of development starting from the planning stage, implementation stage, utilization stage, and evaluation stage. A description of the importance of community participation in development planning includes: a) Community participation is a tool to obtain information about the conditions, needs and attitudes of the local community.

The community will have more confidence in the development activity program if they are involved in its preparation and planning. Hence, they will know more about the ins and outs of the activity program and will have a sense of ownership of the activity program. b) Encouraging public participation because there will be an assumption that it is a democratic right if the communities are involved in development. Village communities can play a role and participate in the preparation of development planning. [2] mentioned that the factors that influence community participation in development planning include: a) Leadership, b) Communication and c) Education. [3] suggests that leaders play a role in guiding, helping, leading, building work motivation, controling the organization, establishing good communication, conducting regular supervision, and directing their subordinates to the goals they want to achieve. Communication can be identified as the delivery of information between two or more people. Communication is also a necessary process to achieve effectiveness [4]. Planned Education, provides the possibility of self-development and tends to be able to work skillfully [5].Law No. 6 of 2014 concerning Villages, the rights and obligations of villages and village communities, it is stated that the village community has the right to: a) Request and obtain information from the Village Government and supervise 
the execution of Village Government activities, implementation of Village Development, Village Community development, and Village community empowerment. b) Obtaining equal and fair service. b) Delivering aspirations, suggestions, and oral or written opinions in a responsible manner regarding the activities of implementing Village Government, implementing Village Development, fostering Village Communities, and empowering Village communities which include: a) Selecting, being elected or determined to be: Village Head, Village Apparatus, Village Consultative Members; or Member of the Village Community Institution. b) Get shelter and protection from disturbances to peace and order in the village.

According to the mandate of Law No. 25 of 2004 concerning the Village Development Planning System, Development Planning is divided into 20-year Long-Term Development Plans, Medium-Term Development Plans and annual Government Work Plans. Village planning itself can be divided into 2 parts, first in the form of the Village Medium-Term Development Plan. The term of the Village Medium Term Development Plan is 6 years, This means that this plan is enforced 6 years after being compiled and established. The second plan is the Village Annual Development Plan or Village Government Work Plan. This plan is an elaboration of the Village Medium Term Development Plan, and the period is one year. Both the Village Medium Term Development Plan and the Village Government Work Plan are then determined in a Village Regulation. The Village Medium Term Development Plan and the Village Government Work Plan are the only planning documents in the Village.

The two plans above are guidelines in the preparation of the Village Revenue and Expenditure Budget which is regulated in a Government Regulation. Planning with a participatory approach is a development strategy and a social determination process. [6] stated that social goals are aimed at ethically responding to the needs and challenges of society through actions to minimize negative impacts. [7] also added that the social aspect must be adjusted to the environment due to the input and output that is going to be achieved. The community must have the awareness to be involved in the development process. The village planning forum is in the form of village development planning deliberation. The substance of village development planning includes setting priorities, programs, activities, and needs for Village Development funded by the Village Revenue and Expenditure Budget, Village community self-help, and/or from the sources of the Regency/City Regional Revenue and Expenditure Budget. Development planning in the Bandar Khalifah village, Percut Sei Tuan District, begins with the Village Development Planning Deliberation, which certainly requires community participation. However, in practice, the problem of participation is still a problem, among others: the lack of enthusiasm for community participation in participating in the Musrenbang due to many of their proposals that have not been realized because of budget constraints and succumbing to development priorities.

Based on the observations, the following problems can be identified: a) The community does not fully understand about community participation in village development planning in Bandar Khalifah Village, Percut Sei Tuan District, which has been running so far. b) The lack of community knowledge related to community participation in village development planning. The objectives of this community service activity are: a) Increase the insight and understanding of community participation in village development planning in Bandar Khalifah Village, Percut Sei Tuan District. b) Sharing knowledge in the implementation of community participation in village development planning in Bandar Khalifah Village, Percut Sei Tuan District. The results of activities that can be accepted by the whole community regarding community participation in village development planning in Bandar Khalifah Village, Percut Sei Tuan District: a) Understand the material about community participation in village development planning in Bandar Khalifah Village, Percut Sei Tuan District. b) Able to implement community participation in village development planning in Bandar Khalifah Village, Percut Sei Tuan District.

\section{METHOD}

This activity will be conducted in Bandar Khalifah Village, Percut Sei Tuan District. in June, 2021. This socialization activity involved village heads and the community in Bandar Khalifah Village, Percut Sei Tuan District and hopefully the participants will be able to implement village development planning 
activities to encourage sustainable achievements. The method used for the implementation of this activity is to conduct socialization through lectures, questions and answers and counseling about community participation in village development planning. In more detail, the method of this activity is as follows: a) Short lecture, used to deliver some informations, assisted by modules and media for learning skills. b) Questions and answers, used during the counseling and counseling process. c) Socialization and counseling, used to show the work steps of each material given. d) Conducting socialization which is centered in Bandar Khalifah Village, Percut Sei Tuan District.

\section{RESULT AND DISCUSSION}

The counseling participants had high enthusiasm with the counseling material provided. This can be seen from the active discussion of the participants from the beginning of the event to the end of the event. Generally, this outreach went well. This is due to the full support of local officials, they are the village head and village officials. Availability of extension facilities and infrastructure and assistance in gathering counseling participants.

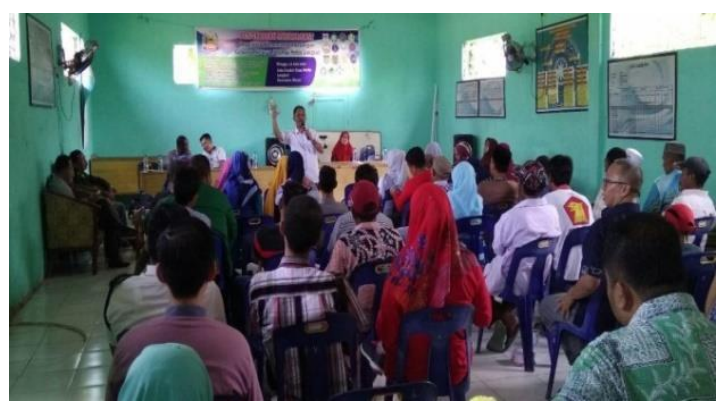

Fig 1. Service implementation in Bandar Khalifah Village,Percut Sei Tuan District.

Development planning can be interpreted as an effort to connect knowledge or techniques based on scientific principles into praxis (practices based on theory) in the perspective of the public or public interest [8]. Based on science, development planning must be maintained by increasing scientific validity and policy relevance. Based on this motive, development planning has developed quite dynamically, both theoretically and paradigmatically. This development can be seen as follows:

Table 1. Character Comparison Of Development Paradigm

\begin{tabular}{|c|c|c|c|}
\hline \multirow{2}{*}{ Character } & \multicolumn{3}{|c|}{ Paradigm } \\
\hline & Growth & basic needs & $\begin{array}{c}\text { Humanist } \\
\text { (People centred dev.) }\end{array}$ \\
\hline Focus & Industry & Service & Human \\
\hline Government's Role & Enterpreneur & Service provider & Enabler/facilitator \\
\hline Main Source & Capital & Budget/Administrative & Creativity/commitment \\
\hline Administration & Vertical & Vertical & Horizontal \\
\hline Structure. & Central & Central/Decentral & Decentral (Bottom up) \\
\hline (Birocracy) & Object & Object & Subject participatory \\
\hline $\begin{array}{l}\text { Planning Process } \\
\text { Participation } \\
\end{array}$ & Marginalization & Budget Limitations & $\begin{array}{l}\text { Attitude structures and } \\
\text { procedures need to be }\end{array}$ \\
\hline Obstacle & & & changed. \\
\hline
\end{tabular}

Source: Modification from [9]

\section{CONCLUSION}

Socialization activities regarding to community participation in village development planning in Bandar Khalifah Village, Percut Sei Tuan District could run well. All participants seemed enthusiastic and felt the benefits. This success is showed by: 1) There was a suitability of the material with the needs of the community to understand the socialization of community participation in village development planning in Bandar Khalifah Village, Percut Sei Tuan District. 2) There was a positive response from the participants. It is indicated by a fairly warm discussion in the context of implementing community participation in village development planning in Bandar Khalifah Village, Percut Sei Tuan District. 


\section{REFERENCES}

[1]. M. Agustin, T. Rahaju. Partisipasi Masyarakat dalam Perencanaan Pembangunan Desa melalui Musrenbang, (Studi Kasus pada Pembangunan Japordes Desa Tunggunjagir Kecamatan Mantup Kabupaten Lamongan), 2016

[2]. M. F. Akbar, S. Suprapto, Surati. Partisipasi Masyarakat Dalam Perencanaan Pembangunan di Desa Jatimulya Kabupaten Boalemo

[3]. L. Nasution, R. N. Ichsan, R. Pengaruh Penerapan Kepemimpinan Terhadap Kinerja Pegawai Pada Kantor Dinas Pendidikan Kabupaten Karo. Jurnal IImiah METADATA, 3(1), 308-320, 2021

[4]. A. R. Syamsuri, A. Halim, D. Darvita. Analisis Adversity Quotient dan Komunikasi Interpersonal dengan Komitmen Organisasi sebagai Intervening terhadap Produktivitas Karyawan, Ecobisma (Jurnal Ekonomi, Bisnis dan Manajemen), 7(2), 125-139, 2020

[5]. A. R. Syamsuri, Analisis Pengaruh Pendidikan, Pengawasan Kerja dan Disiplin terhadap Kinerja Pegawai Dinas Pendidikan Kabupaten Mandailing Natal, Ecobisma (Jurnal Ekonomi, Bisnis dan Manajemen), 1(1), 44-55, 2021

[6]. R. N. Ichsan. L. Nasution, S. Sinaga. Bahan Ajar Manajemen Sumber Daya Manusia (MSDM), Sentosa Deli Mandiri, 2021.

[7]. R. N. Ichsan. L. Nasution, S. Sinaga. Studi kelayakan bisnis (Business feasibility study) Sentosa Deli Mandiri, 2019.

[8]. I. Nugroho, R. Dahuri. Pembangunan Wilayah: Perspektif Ekonomi, Sosial dan Lingkungan. Jakarta: LP3ES, 2004

[9]. A. M. W. Pranarka dan Vidhandika Moeljarto, Pemberdayaan (Empowerment): Konsep, Kebijakan dan Implementasi.Jakarta: CSIS, 2004 